\title{
Standardization of Processing Technologies for the Preparation of Restructured Buffalo Meat Steaks
}

Giriprasad Ramasamy*, Brahma Deo Sharma, Heena Sharma and Suman Talukder

Division of Livestock Products Technology, Indian Veterinary Research Institute, Izatnagar-243 122, Uttar Pradesh, India

\begin{abstract}
Appropriate binding of meat pieces and high water retention are two most important factors in marketing high quality restructured meat products. Here, the processing technologies viz massaging time and cooking time play pivotal role and can improve the appearance, palatability and texture of the finished products. and under this study, the quality of Restructured Buffalo Meat Steaks (RBMS) prepared with three different massaging times viz., 10(7+3), 12(9+3) and 15(12+3) minutes and cooking time viz., 40, 45 and 50 minutes was evaluated. It was found that cooking yield of the steaks prepared with 15 minutes massaging time was significantly higher $(P<0.05)$ than 10 and 12 minutes and sensory scores revealed no significant difference $(P>0.05)$ between different massaging time. However, there was a significant reduction $(P<0.05)$ in the product yield with each increase in cooking time. Based on cooking yield and sensory attributes, 15 minutes massaging time and cooking time of 40 minutes was considered optimum for product preparation.
\end{abstract}

Keywords: Restructured buffalo meat steaks; Massaging time; Cooking time; Cooking yield; Sensory attributes

\section{Introduction}

India with immense livestock wealth claims a remarkable 58 per cent of the world's buffalo population (106.63 millions) produces 1.42 MT of buffalo meat, accounting for $24.4 \%$ of total meat production of the country [1]. As per APEDA [2], only $2 \%$ of the total meat is processed in India. So, processing of buffalo meat is essential to exploit its undermined potential. In India, buffalo meat is primarily produced from aged/spent animals (about 12-15 years) after their productive/ reproductive life is over. Meat from such aged/spent animals is tough, less juicy, and characterized by high amounts of connective tissue. This coarse textured meat needs to be subjected to special processing and cooking methods to improve tenderness [3]. Thus, the abundantly available low-cost buffalo meat from spent animals has vast potential for production of several value added convenience meat products.

Restructuring of meat products enables the use of less valuable meat components to produce high quality meat products at reduced cost [4]. Therefore, the enhanced use of low-priced cuts and/or raw material from mature animals can be achieved using restructured meat technology. Meat to meat binding in restructured meat products may be achieved through the formation of gels that set thermally (hot-set) or chemically (cold-set). Conventional restructured meat products depend on the hot-set binding of myofibrillar proteins that are extracted from the meat with the combined effects of salt, phosphate and mechanical action [5]. Booren et al. [6] found that there was a significant linear increase in binding strengths till $12 \mathrm{~min}$ of mixing at $2^{\circ} \mathrm{C}$.

In view of the above considerations, it was proposed to develop novel restructured buffalo meat steaks from spent animals and thus, various processing technologies were standardized in order to improve the palatability and texture of the product.

\section{Source of Buffalo meat}

Buffalo meat free from external fat was obtained from rounds of spent adult female buffalo carcass within 5-6 hours after slaughter from meat market of Bareilly. All visible fascia and external fat was trimmed off and meat portions were made into cuts of approximately $0.5 \mathrm{~kg}$. The cuts were then packaged separately in Low Density Polyethylene
(LDPE) pouches and kept in refrigerator $\left(4 \pm 1^{\circ} \mathrm{C}\right)$ for conditioning for about 24 hours. Thereafter, the samples were shifted to deep freezer (Blue Star, FS345, Denmark) for storage at $-18 \pm 2^{\circ} \mathrm{C}$ until further use.

\section{Non-meat ingredients}

Spice ingredients were purchased from the local market of Bareilly and freed from extraneous matter. These were dried in hot air oven at $50^{\circ} \mathrm{C}$ for 4 hours and grounded and sieved through a fine mesh. The different spice ingredients used for preparation of spice mix were mixed in suitable proportion (Table 1). For the preparation of condiments, onion was peeled off, cut into small pieces and homogenized in a mixer to obtain a fine paste. Garlic paste was purchased from the local market of Bareilly.

\section{Preparation of restructured buffalo meat steaks}

Chunking: Frozen meat in LDPE packages was thawed (approx. $16 \mathrm{~h}$ at $4 \pm 1^{\circ} \mathrm{C}$, reaching between -3 and $-5^{\circ} \mathrm{C}$ ) (Figure 1 ). The partially thawed meat was carefully trimmed off from adhering visible loose connective tissue and fascia was sliced across the grain into $1 \mathrm{~cm}$ thick slices. The sliced buffalo meat was then cut along and across to chunks of nearly $1 \mathrm{~cm}^{3}$. Temperature of the meat chunks was maintained below $2^{\circ} \mathrm{C}$ by keeping it immediately in a refrigerator at $0^{\circ} \mathrm{C}$ after chunking, so as to ensure temperature of meat chunks below $10^{\circ} \mathrm{C}$ throughout the processing.

Curing solution formulation: The processing of the restructured buffalo meat steaks was done using suitable ingredients in curing solution formulation for restructured buffalo meat blocks (Table 2).

*Corresponding author: Giriprasad Ramasamy, Division of Livestock Products Technology, Indian Veterinary Research Institute, Izatnagar-243 122, Uttar Pradesh India, Tel +917599058135; E-mail: drgirivet58@gmail.com

Received June 23, 2014; Accepted August 30, 2014; Published September 11, 2014

Citation: Ramasamy G, Sharma BD, Sharma H, Talukder S (2014) Standardization of Processing Technologies for the Preparation of Restructured Buffalo Meat Steaks. J Food Process Technol 5: 366. doi:10.4172/2157-7110.1000366

Copyright: ( 2014 Ramasamy G, et al. This is an open-access article distributed under the terms of the Creative Commons Attribution License, which permits unrestricted use, distribution, and reproduction in any medium, provided the original author and source are credited. 
Citation: Ramasamy G, Sharma BD, Sharma H, Talukder S (2014) Standardization of Processing Technologies for the Preparation of Restructured Buffalo Meat Steaks. J Food Process Technol 5: 366. doi:10.4172/2157-7110.1000366

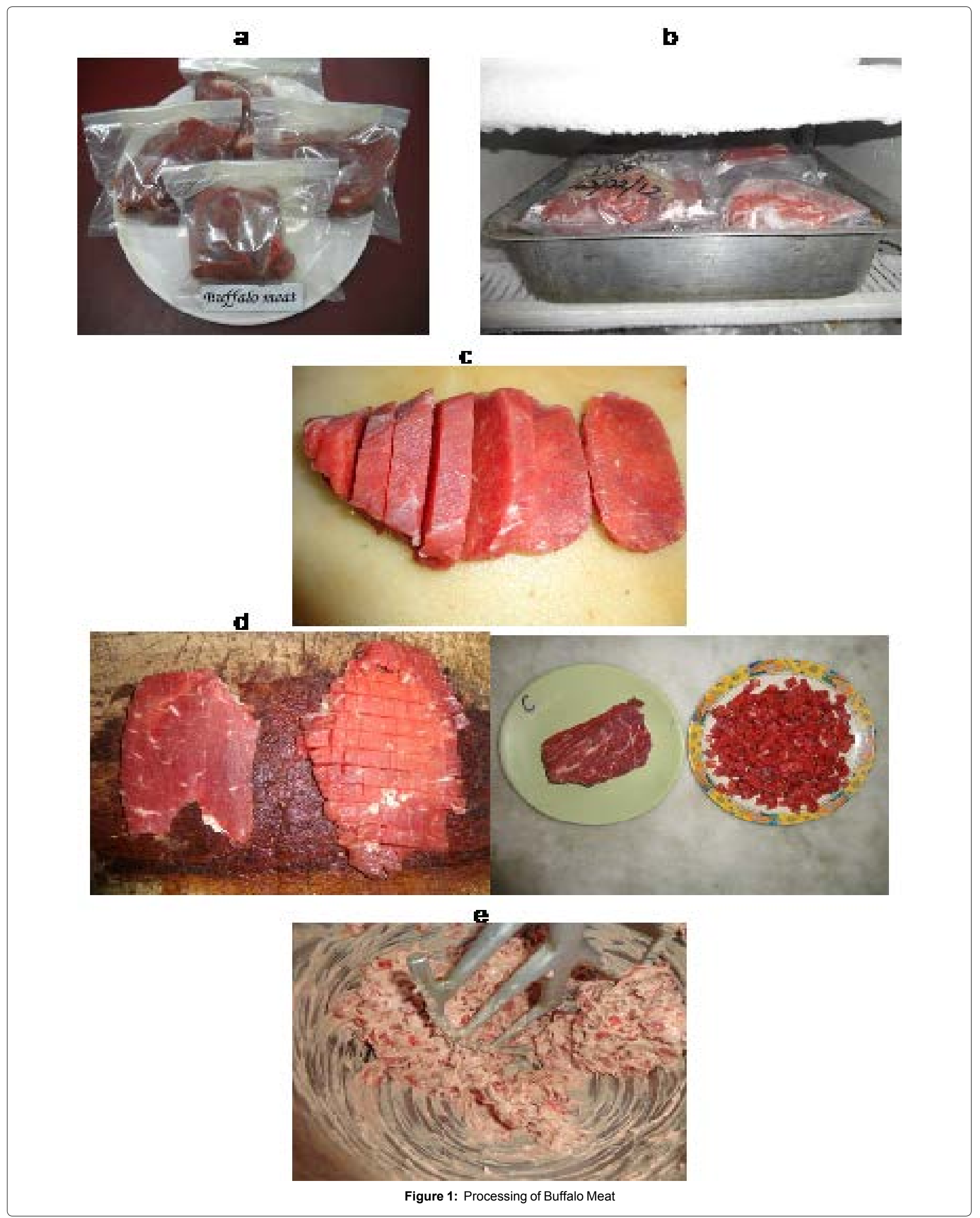


Citation: Ramasamy G, Sharma BD, Sharma H, Talukder S (2014) Standardization of Processing Technologies for the Preparation of Restructured Buffalo Meat Steaks. J Food Process Technol 5: 366. doi:10.4172/2157-7110.1000366

Page 3 of 4

\begin{tabular}{|l|c|}
\hline Ingredients & Percentage \\
\hline Coriander powder (Dhaniya) & 17 \\
\hline Cumin seed (Jeera) & 10 \\
\hline Aniseed (Soanf) & 10 \\
\hline Black pepper (Kalimirch) & 10 \\
\hline Caraway seed (Ajowan) & 10 \\
\hline Turmeric (Haldi) & 10 \\
\hline Dried ginger & 10 \\
\hline Capsicum (Mirch powder) & 8 \\
\hline Cardamom (BadaElaichi) & 5 \\
\hline Cinnamon (Dal chini) & 5 \\
\hline Cloves (Laung) & 3 \\
\hline Nutmeg (Jaibhal) & 1 \\
\hline Lace (Jaipatri) & 1 \\
\hline Total & 100 \\
\hline
\end{tabular}

Table 1: Formulation of spice mix used for the preparation of restructured buffalo meat steaks.

\begin{tabular}{|l|c|}
\hline Ingredients & Quantity \\
\hline Sodium chloride(g) & $120.0 \mathrm{~g}$ \\
\hline Cane sugar(g) & 60.00 \\
\hline Sodium tripolyphosphate(g) & 25.00 \\
\hline Monosodium glutamate (MSG)(g) & 0.05 \\
\hline Sodium nitrite(g) & 0.75 \\
\hline Water(ml) & 1000.00 \\
\hline
\end{tabular}

Table 2: Formulation of curing solution.

In this study, massaging technique was used for the preparation of restructured buffalo meat steaks. The ingredients were dissolved, mixed well and then filtered. $200 \mathrm{ml}$ curing solution was used for massaging of $1 \mathrm{~kg}$ of buffalo meat chunks.

Forming to restructured steaks: Meat chunks in semi frozen state were placed in paddle mixture (HOBART, Model: N50G) and massaging was done initially at low speed with simultaneous addition of curing solution which facilitated the extraction of muscle proteins from meat and formed a tacky exudate to bind meat pieces. Then, nonmeat additives such as refined wheat flour, spices, and condiments were added in order and concurrently mixed/blended for few minutes at medium speed for uniform mixing. Once each mixing time was achieved, the meat was unloaded from the mixer, weighed and stuffed into stainless steel moulds. Moulds were squeezed with wooden press to remove air pockets.

Once ready, the batter prepared was stuffed in stainless steel moulds which were closed tightly and placed in pressure cooker filled with $1 / 3$ boiling hot water and then cooked by steam without pressure. Slow heating rate was ensured by adjusting the flame regulating knob (Code: 637470, Regalia, Sun flame) to low, so that the required internal temperature $85^{\circ} \mathrm{C}$ of the product was achieved. The formulation of restructured buffalo meat steaks is given in Table 3 .

\section{Experimental plan}

Standardization of massaging time for processing of restructured buffalo meat steaks: Three batches, each containing 500 $\mathrm{g}$ of buffalo meat chunks $\left(1 \mathrm{~cm}^{3}\right)$ were put in paddle mixer along with other ingredients and respectively massaged for three different timings viz., 10 minutes ( 7 minutes of initial mixing of meat and non-meat ingredients +3 minutes of additional mixing), 12 minutes $(9+3)$ and 15 minutes $(12+3)$. The mix obtained was stuffed in stainless steel moulds and cooked by steam without pressure for 45 minutes. Based on the sensory attributes and cooking yield, optimum massaging time was selected.

Standardization of cooking time for processing of restructured buffalo meat steaks: For the standardization of cooking time, $1500 \mathrm{~g}$ of buffalo meat chunks were put in paddle mixer along with other ingredients and massaged for fixed time (selected as per above experiment). Mix obtained was stuffed into three different stainless steel moulds and cooked in steam without pressure for three different timings viz., 40 minutes, 45 minutes and 50 minutes. Based on the core temperature, sensory attributes and cooking yield, optimum cooking time was used for further experiment.

Sensory analysis: Sensory evaluation method using an 8 point descriptive scale [7] was followed, where $8=$ like extremely; 1 = dislike extremely. The sensory panel consisted of seven trained scientists and post graduate students of the division. Three digit coded samples were served to the panelists in random order. They were explained

\begin{tabular}{|l|c|}
\hline Ingredients & Control \\
\hline Lean meat $(\mathrm{g} / 100 \mathrm{~g})$ & 75.00 \\
\hline Curing solution $(\mathrm{g} / 100 \mathrm{ml})$ & 15.00 \\
\hline Refined wheat flour $(\mathrm{g} / 100 \mathrm{~g})$ & 3.00 \\
\hline Spice Mix $(\mathrm{g} / 100 \mathrm{~g})$ & 2.00 \\
\hline Condiments $(\mathrm{g} / 100 \mathrm{~g})$ & 5.00 \\
\hline
\end{tabular}

Table 3: General formulation for restructured buffalo meat steaks.

\begin{tabular}{|l|c|c|c|}
\hline \multirow{2}{*}{ Parameters } & \multicolumn{3}{|c|}{ Massaging time } \\
\cline { 2 - 4 } & $\mathbf{1 0} \mathbf{~}$ in & 12 $\mathbf{~ m i n}$ & $\mathbf{1 5} \mathbf{~}$ in \\
\hline Cooking yield (\%) $\dagger$ & $87.75 \pm 0.56^{\mathrm{b}}$ & $87.82 \pm 0.65^{\mathrm{b}}$ & $90.18 \pm 0.46^{\mathrm{a}}$ \\
\hline Sensory attributes $\ddagger$ & & \\
\hline General appearance & $6.80 \pm 0.12$ & $7.00 \pm 0.11$ & $6.91 \pm 0.13$ \\
\hline Flavor & $6.85 \pm 0.10$ & $6.84 \pm 0.11$ & $6.85 \pm 0.13$ \\
\hline Juiciness & $6.80 \pm 0.10$ & $6.71 \pm 0.14$ & $6.72 \pm 0.14$ \\
\hline Texture & $6.94 \pm 0.10$ & $6.79 \pm 0.16$ & $6.79 \pm 0.14$ \\
\hline Binding & $6.80 \pm 0.11$ & $6.85 \pm 0.14$ & $6.90 \pm 0.13$ \\
\hline Overall acceptability & $6.92 \pm 0.08$ & $6.97 \pm 0.10$ & $6.91 \pm 0.12$ \\
\hline
\end{tabular}

*Mean values are scores on 8-point descriptive scale where 1: extremely undesirable and 8: extremely desirable.

Mean \pm SE bearing different superscripts in a row differ significantly $(P<0.01)$ $\lceil n=6$ and $\ddagger n=21$ for each treatment

Table 4: Effect of massaging time on cooking yield and sensory attributes of restructured buffalo meat steaks (Mean $\pm \mathrm{SE})^{\star}$.

\begin{tabular}{|l|c|c|c|}
\hline \multirow{2}{*}{ Parameter } & \multicolumn{3}{|c|}{ Cooking time } \\
\cline { 2 - 4 } & $\mathbf{4 0} \mathbf{~ m i n}$ & $\mathbf{4 5} \mathbf{~ m i n}$ & $\mathbf{5 0} \mathbf{~ m i n}$ \\
\hline Cooking yield (\%) $\dagger$ & $87.08 \pm 0.93^{\mathrm{a}}$ & $83.15 \pm 0.90^{\mathrm{b}}$ & $78.53 \pm 0.67^{\mathrm{c}}$ \\
\hline Sensory attributes $\ddagger$ & & & \\
\hline Appearance & $7.05 \pm 0.11$ & $7.00 \pm 0.12$ & $7.05 \pm 0.11$ \\
\hline Flavor & $7.12 \pm 0.10$ & $7.02 \pm 0.10$ & $7.15 \pm 0.12$ \\
\hline Juiciness & $7.22 \pm 0.09^{\mathrm{a}}$ & $6.88 \pm 0.09^{\mathrm{b}}$ & $6.65 \pm 0.10^{\mathrm{b}}$ \\
\hline Texture & $7.00 \pm 0.06^{\mathrm{a}}$ & $6.66 \pm 0.09^{\mathrm{b}}$ & $6.60 \pm 0.09^{\mathrm{b}}$ \\
\hline Binding & $7.04 \pm 0.07$ & $6.91 \pm 0.16$ & $6.91 \pm 0.19$ \\
\hline Overall acceptability & $7.06 \pm 0.09$ & $7.01 \pm 0.11$ & $6.92 \pm 0.10$ \\
\hline
\end{tabular}

*Mean values are scores on 8-point descriptive scale where 1: extremely undesirable and 8: extremely desirable.

Mean \pm SE bearing different superscripts in a row differ significantly $(P<0.01)$

$\dagger \mathrm{t}=6$ and $\ddagger \mathrm{n}=21$ for each treatment *Mean values are scores on 8-point descriptive scale where 1: extremely undesirable and 8: extremely desirable.

Mean \pm SE bearing different superscripts in a row differ significantly $(P<0.01)$ $\dagger \mathrm{n}=6$ and $\ddagger \mathrm{n}=21$ for each treatment

Table 5: Effect of cooking time on cooking yield and sensory attributes of restructured buffalo meat steaks (Mean \pm S.E.) ${ }^{*}$. 
about the nature of experiment without disclosing the identity of the samples. Taste panel were organized around 3.30-4.00 pm every time. The sensory panelists were asked to rate their preference on 8 point descriptive scale on the sensory evaluation proforma for general appearance, flavour, juiciness, texture, binding and overall palatability. Potable water was provided to rinse the mouth in between the samples.

Statistical analysis: The statistical design of the study was 4 (treatments) $* 3$ (replications) randomized block design. All physical and chemical determinations were done in triplicate. There were seven sensory determinations for each treatment-replication combination. The data generated from various trials under experiment were pooled, processed and analyzed by statistical method of one way-ANOVA and Mean \pm S.E using SPSS software package developed as per the procedure of Snedecor and Cochran [8]. Duncan's multiple range test [9] and critical difference were determined at the 5\% significance level.

\section{Results and Discussion}

\section{Massaging}

Cooking yield at $15 \mathrm{~min}(12+3)$ massaging time was significantly higher $(\mathrm{P}<0.01)$ than at $10(7+3)$ and $12(9+3) \mathrm{min}$; however, no significant difference was observed between $10(7+3)$ and $12(9+3) \mathrm{min}$ (Table 4). The result was in agreement with the findings of Lachowicz et al.; Pietrasik et al.; Gurikar et al.; and Moon et al. [10-13] who reported that the products tumbled for a longer time had a lower cooking loss due to increased amount of extractable salt soluble proteins, as compared to those tumbled for a short time. Sensory scores revealed no significant difference $(\mathrm{P}>0.05)$ between $10(7+3), 12(9+3)$ and 15 $(12+3)$ min massaging time on quality attributes of RBMS; however, the binding scores increased marginally with increased massaging time. It appeared that longer massaging time was required for buffalo meat due to stronger collagen connections and differences in the muscle structure to incorporate brine into the muscle cells and to provide more favorable conditions for protein solubilization, extraction and binding which formed the base of restructuring technology. Booren et al.; Durland et al.; Coon et al. and Noble et al. [14-17] reported that optimal mixing times for restructured meat products varied from experiment to experiment. Thus, on the basis of cooking yield and above considerations, $15 \mathrm{~min}$ was taken as optimum for preparation of RBMS and used for further studies.

\section{Cooking time}

Mean values of cooking yield with different cooking times viz. 40, 45 and 50 min showed that there was a significant reduction $(\mathrm{P}<0.01)$ in the product yield with each increase in cooking time (Table 5). The result was in agreement with the findings of Gurikar et al., in restructured pork blocks. The reason for this reduction could be due to a greater degree of shrinkage of the muscle fibers and protein coagulation [18]. The core temperature was recorded at 40,45 and 50 minutes with the help of probe thermometer. It was found that RBMS attained the core temperature of $83 \pm 2^{\circ} \mathrm{C}$ within 40 minutes. Sensory scores revealed that there was no significant difference $(\mathrm{P}>0.05)$ in the scores of general appearance, flavor, binding and overall acceptability between different cooking times. However, there was a significant reduction $(\mathrm{P}<0.01)$ in juiciness and texture scores at higher timetemperature combinations. The reason for such reduction may be due to increased toughness caused by increased cooking loss and collagen shrinkage at high temperatures. Barbut and Findlay [19] reported that binding of meat chunks in restructured meat products during cooking involved a balance of protein-protein interactions and protein-water interactions as a result of heat denaturation of proteins. At high timetemperature combinations, balance of these interactions might be affected and influenced the scores of juiciness, texture and structural binding. Hence, optimum cooking time of 40 minutes was selected for further studies in view of higher product yield and sensory attributes including juiciness and texture.

\section{References}

1. FAO (2009) Food and Agriculture Organization of the United Nations, Rome. FAOSTAT.

2. APEDA (2008) Export of agro and processed food products including meat and meat products. Agricultural and Processed Food Products Export Development Authority. Ministry of Commerce, Government of India.

3. Hedrick HB, Aberle ED, Forrest JC, Judge MD, Merkel RA (1994) Principles of Meat Science. Kendall/Hunt Publishing Company, Dubuque, lowa, USA

4. Tsai SJ, Unklesbay N, Unklesbay K, Clarke A (1998) Water and absorption properties of restructured beef products with five binders at four isothermal temperatures. Lebensm Wiss Technol 31: 78-83.

5. Boles JA, Shand PJ (1998) Effect of comminution method and raw binding system in restructured beef. Meat Sci 49: 297-307.

6. Booren AM, Mandigo RW, Olson DG, Jones KW (1982) Characterization of exudate proteins involved in binding meat pieces into a sectioned and formed beef steak. J Food Sci 47: 1943-1947.

7. Keeton JT (1983) Effect of fat and Nacl/phosphate levels on the chemical and sensory properties of pork patties. J Food Sci 48: 878-885.

8. Snedecor GW, Cochran WG (1995) Statistical methods. (8thedn). IOWA State University Press, Ames, IOWA.

9. Duncan DB (1955) Multiple range and multiple $F$ test. Biometrics 11: 1-42.

10. Lachowicz K, Gajowiecki L, Zych A, Sobczak M (2003) Effect of massaging time on texture, rheological properties and structure of three pork ham muscle. Meat Sci 63: 225-233.

11. Pietrasik Z, Shand PJ (2004) Effect of blade tenderization and tumbling time on the processing characteristics and tenderness of injected cooked roast beef Meat Sci 66: 871-879.

12. Gurikar AM, Lakshmanan V, Gadekar YP, Sharma BD, Anjaneyulu ASR (2014) Effect of meat chunk size, massaging time and cooking time on quality of restructured pork blocks. J Food Sci Technol 51: 1363-1369.

13. Moon SS, Yang HS, Park GB, Joo ST (2007) The effect of tumbling time on the quality and binding ability of restructured beef $\mathrm{m}$. pectoralisprofundus with alginate binder. Asian Austral J Anim 20: 418-423.

14. Booren AM, Mandigo RW, Olson DG, Jones KW (1981) Effect of muscle type and mixing time on sectioned and formed beef steaks. J Food Sci 46: 16651672.

15. Durland PR, Seideman SC, Costello WJ, Quenzer NM (1982) Physical and sensory properties of restructured beef steaks formulated with various flake sizes and mixing times. J Food Protect 45: 127-131.

16. Coon FP, Calkins CR, Mandigo RW (1983) Pre- and post-rigor sectioned and formed beef steaks manufactured with different salt levels, mixing times and tempering times. J Food Sci 48: 1731-1734.

17. Noble BJ, Seideman SC, Quenzer NM, Costello WJ (1985) The effect of slice thickness and mixing time on the palatability and cooking characteristics of restructured beef steaks. J Food Quality 7: 201-208.

18. Asghar A, Pearson AM (1980) Influence of ante- and post-mortem treatments upon muscle composition and meat quality. Adv Food Res 26: 53-213.

19. Barbut S, Findlay CJ (1989) Sodium reduction in poultry products: A review. Crit Rev Poult Bio 2: 59. 